\title{
Article \\ CAPPRIC Study-Characterization of Community-Acquired Pneumonia in Spanish Adults Managed in Primary Care Settings
}

\author{
Jesús Molina ${ }^{1, *}$, Amelia González-Gamarra ${ }^{2}$, Leovigildo Ginel ${ }^{3}{ }^{\circledR}, \mathbf{M}^{a}$ Encarnación Peláez $^{4}$, Juan Luis Juez ${ }^{5}$, \\ Antonio Artuñedo ${ }^{6}$, Gonzalo Aldana ${ }^{7}$, Enriqueta Quesada ${ }^{8}$, Joan Josep Cabré ${ }^{9}$, Antonio Gómez ${ }^{10}$, \\ Manuel Linares ${ }^{11}$, Maria Teresa Marín ${ }^{12}$, Pilar Yolanda Sanchez ${ }^{13}$, Leonor Núñez ${ }^{14}$, Jaime Gonzálvez ${ }^{15}$ (D), \\ Enrique Mascarós ${ }^{16}{ }^{\circledR}$, Javier López ${ }^{17}$, Agustina Cano ${ }^{18}$, José Herrero ${ }^{19}$, María Carmen Serra ${ }^{20}$, Enrique Cimas ${ }^{21}$, \\ Marta Pedrol ${ }^{22}$, Juan Vicente Alfaro ${ }^{23}$, Federico Martinón-Torres ${ }^{24} \odot$, Isabel Cifuentes ${ }^{25}$, Cristina Méndez ${ }^{25}$, \\ Daniel Ocaña ${ }^{26}$ and on behalf of the CAPPRIC study group ${ }^{+}$
}

Citation: Molina, J.;

González-Gamarra, A.; Ginel, L.;

Peláez, M.E.; Juez, J.L.; Artuñedo, A.;

Aldana, G.; Quesada, E.; Cabré, J.J.;

Gómez, A.; et al. CAPPRIC

Study-Characterization of

Community-Acquired Pneumonia in Spanish Adults Managed in Primary Care Settings. Microorganisms 2021, 9 , 508. https://doi.org/10.3390/

microorganisms 9030508

Academic Editor: Harsharn Gill

Received: 21 December 2020

Accepted: 24 February 2021

Published: 28 February 2021

Publisher's Note: MDPI stays neutra with regard to jurisdictional claims in published maps and institutional affiliations.

Copyright: (C) 2021 by the authors Licensee MDPI, Basel, Switzerland. This article is an open access article distributed under the terms and conditions of the Creative Commons Attribution (CC BY) license (https:// creativecommons.org/licenses/by/ $4.0 /)$

\author{
Primary Health Care Center Francia, Fuenlabrada, 28943 Madrid, Spain \\ Primary Health Care Center Goya, 28009 Madrid, Spain; amelia.gamarra@gmail.com \\ Primary Health Care Center Ciudad Jardín, 29014 Málaga, Spain; lginel@gmail.com \\ Primary Health Care Center Puerta Blanca, 29004 Málaga, Spain; encarnitapg@hotmail.com \\ Primary Health Care Center Urban, 48901 Barakaldo, Spain; juanluis.juezsenovilla@osakidetza.net \\ Primary Health Care Center Nova Lloreda, 08917 Badalona, Spain; antoartugonza@gmail.com \\ Primary Health Care Center Burriana II, 12530 Burriana, Spain; aldana_gon@gva.es \\ 8 Primary Health Care Service, Hospital de Alta Resolución "El Toyo", 04131 Almería, Spain; \\ quetiquesada@hotmail.com \\ 9 Primary Health Care Center Sant Pere, 43202 Reus, Spain; jcabre.tarte.ics@gencat.cat \\ 10 Primary Health Care Center Fernando el Católico, 50009 Zaragoza, Spain; agpeligros@gmail.com \\ 11 Primary Health Care Center Buenos Aires, 28038 Madrid, Spain; manuellinares@fundacionio.com \\ 12 Primary Health Care Center General Ricardos, 28019 Madrid, Spain; maite_marin@telefonica.net \\ 13 Primary Health Care Center Actur Sur, 50018 Zaragoza, Spain; ysanchez@comz.org \\ 14 Primary Health Care Center Barrio de la Salud, 38007 Santa Cruz de Tenerife, Spain; Leonuchi@gmail.com \\ 15 Primary Health Care Center Matamá, 36312 Vigo, Spain; gonzalvez.jaime@gmail.com \\ 16 Primary Health Care Center Fuente San Luis, 46013 Valencia, Spain; enmasba@gmail.com \\ 17 Primary Health Care Center Utrera Norte Príncipe de Asturias, 41710 Utrera, Spain; \\ lopezantonioj95c@gmail.com \\ 18 Primary Health Care Center García Noblejas, 28037 Madrid, Spain; tinacano60@msn.com \\ 19 Primary Health Care Center Los Comuneros, 09006 Burgos, Spain; joseherreroroa@gmail.com \\ 20 Primary Health Care Center Just Ramírez, 46009 Valencia, Spain; maria.serrabartual39@gmail.com \\ 21 Primary Health Care Center Contrueces, 33210 Gijón, Spain; jcimash@gmail.com \\ 22 Primary Health Care Center Sant Llàtzer, 08221 Terrasa, Spain; MPedrol@CST.CAT \\ 23 Primary Health Care Center Murcia Centro-San Juan, 30003 Murcia, Spain; jvalfarog@hotmail.com \\ 24 Genetics, Vaccines and Pediatric Infectious Diseases Research Group (GENVIP), Healthcare Research Institute \\ of Santiago de Compostela, 15706 Santiago de Compostela, Spain; federico.martinon.torres@sergas.es \\ 25 Medical Department, Pfizer S.L.U., Alcobendas, 28108 Madrid, Spain; cifuentesotero@pfizer.com (I.C.); \\ Cristina.mendezdiez@pfizer.com (C.M.) \\ 26 Primary Health Care Center Algeciras-Norte, 11205 Algeciras, Spain; ficusficus@gmail.com \\ * Correspondence: jmolinaparis@gmail.com \\ + Full list of the CAPPRIC study group members is included at the end of the article.
}


(95\% CI $=13.9-15.3), 65.4 \%$ of patients had recovered. Hospitalization rate was $2.8 \%$. The most frequently prescribed antibiotics were quinolones (58.7\%) and $\beta$-lactams (31.1\%). In conclusion, one-third of CAP patients did not fully recover after two weeks of empiric antibiotic therapy and $2.8 \%$ required hospitalization, highlighting the significant burden associated with non-hospitalized CAP in Spain.

Keywords: CAP; ambulatory; non-hospitalized; outpatient; pneumococcal CAP; communityacquired pneumonia

\section{Introduction}

Lower respiratory infections have been a leading global infectious cause of mortality in all age groups over the past twenty-five years [1]. Among them, community-acquired pneumonia (CAP) is a major cause of morbidity and mortality worldwide, especially in the elderly. It is responsible for approximately 1 million hospital admissions yearly, producing a considerable impact on health care resources. The incidence of CAP is highly variable and differs depending on the country, study population, setting and study approach. In the USA, for instance, the reported incidence of CAP requiring hospitalization between 2014-2016 was 6.5 patients per 1000 adults [2], while in Europe, the incidence of CAP ranged from 7.6 to 14 cases per 1000 adults in patients older than 65 years [3]. In Spain specifically, the incidence of CAP in primary care patients $\geq 65$ years was $24.8-94.8$ per 1000 persons [4]. However, most of these studies are based only on hospital data, although the majority of CAP patients receive outpatient treatment [5].

The diagnosis of CAP is primarily based on clinical manifestations and signs of lower respiratory tract infections. Suspected CAP should be confirmed by chest radiography and microbiological testing. However, despite various diagnostic tests currently available for CAP, its etiology is only identified in around 50\% of cases [6]. Among the different possible causative CAP agents, the bacteria Streptococcus pneumoniae (S. pneumoniae) is the most frequently identified pathogen [7]. In fact, it was found to be the leading cause of lower respiratory infection morbimortality at a global level during 1990-2016 [8]. Its prevalence in CAP is usually underestimated due to a lack of sensitive and specific tests. A traditional diagnostic approach for CAP includes blood or sputum culture [9], but although cultures are very specific to confirm the etiology of the disease, they are not routinely used in primary care facilities. Alternatively, non-invasive rapid tests like Binax Now ${ }^{\circledR}$ allow the specific identification of $S$. pneumoniae antigen in CAP patients by detecting urinary C-polysaccharide antigen, a component of the pneumococcal cell wall that is excreted in the urine [10].

Most studies on CAP have been based on hospitalized patients, yet most patients with CAP are treated on an outpatient basis. Only a few epidemiological studies have focused on the contribution of CAP treated in an ambulatory setting in Spain $[4,11]$, and these are restricted to specific regions or age groups. The last Spanish epidemiologic study on CAP in primary care was performed between 2009 and 2013 [4], reinforcing the need for up-to-date data on this specific population.

Despite the recognized importance of ambulatory CAP in adults, there are scant data in the literature regarding the burden of the disease in this setting. This prospective study aimed to analyze the clinical characteristics, management, and evolution of radiologically confirmed CAP in adults seen in primary care centers in Spain during a three-year period (2016-2019). 


\section{Materials and Methods}

\subsection{Study Design}

This prospective, multicenter, population-based active surveillance study was designed to evaluate the incidence and characteristics of ambulatory CAP confirmed by chest radiography in adults treated in 24 primary care centers between April 2016 and April 2019.

The study was conducted in accordance with the Declaration of Helsinki, and the protocol was reviewed and approved by the Institutional Ethics Committee of Madrid (Spain) (reference PFI-PRE-2015-01) and at all participating centers, according to local standards. Informed consent was obtained from all patients. The study was non-interventional, and patients were managed according to the criteria of their treating physicians.

\subsection{Patients}

Eligible participants were adults 18 years of age or older who visited participating primary care physicians at study sites and had signs and symptoms of pneumonia, including two or more of the following: fever (temperature $>38^{\circ} \mathrm{C}$ ) within $24 \mathrm{~h}$ prior to recruitment, hypothermia $\left(<35.5^{\circ} \mathrm{C}\right)$ measured by a healthcare professional within $24 \mathrm{~h}$ prior to recruitment, shaking chills, pleuritic chest pain, cough, expectoration, dyspnea, tachypnea, general discomfort, auscultation abnormalities indicative of pneumonia (crackles) or indications of lung consolidation (dullness on percussion, bronchial breath sounds, or egophony).

Patients who required hospitalization at study inclusion in the opinion of the physician were excluded from the study. Other exclusion criteria included: the presence of CAP within the 60 days prior to the screening visit; hospital inpatient; diagnosis of active pulmonary tuberculosis according to the medical history; post-obstructive pneumonia due to lung cancer, vaccination with a pneumococcal vaccine in the 10 days prior to the screening visit; previous recruitment in this study in the 60 days prior to the screening visit; and pregnant or potentially pregnant women at screening visit.

After giving their written informed consent, patients underwent the following selection procedures to be finally included in the study: (i) Collection of a urine sample for pneumococcal antigen testing (Binax $\operatorname{Now}^{\circledR}$ ); and (ii) Chest x-ray performed according to standard clinical practice within $72 \mathrm{~h}$ before or after selection for the study.

The Binax Now ${ }^{\circledR}$ test was performed according to the manufacturer's instructions [12].

\subsection{Outcomes}

The main study objective was to analyze the clinical characteristics, management and evolution of CAP confirmed by chest radiography in adults 18 years of age and older in ambulatory care in Spain. We also aimed to specifically identify the proportion of pneumococcal CAP using the Binax Now ${ }^{\circledR}$ test in urine.

Secondary objectives included description of the demographic characteristics, underlying diseases, and risk factors in CAP patients $\geq 18$ years. We also estimated the incidence rate of ambulatory radiographically confirmed CAP in those centers where a population denominator was established.

The incidence rate of outpatient CAP was calculated in the four participating centers (Burriana II, Urban, Buenos Aires and Ciudad Jardín) where a population denominator could be established. These primary care centers belonged to different geographical regions in Spain (Valencian Community, Basque Country, Community of Madrid, and Andalusia). All patients $\geq 18$ years with CAP confirmed by chest $X$-ray during the study recruitment period were included.

\subsection{Statistical Analysis}

In order to determine the percentage of pneumococcal CAP confirmed both by radiography and the Binax Now ${ }^{\circledR}$ assay, a descriptive analysis of all the variables was performed. Study estimates were made with a $95 \%$ confidence interval (significance was considered as 
a $p$-value $<0.05)$. All calculations were done using the SAS Enterprise Guide 7.1 statistical package (SAS Institute Inc., Cary, NC, USA).

\section{Results}

\subsection{Patient Characteristics}

Among 851 adult patients with CAP registered between April 2016 and April 2019 in 24 Spanish primary care centers, 524 patients were considered for inclusion in the study. Of these, $68(12.5 \%)$ were ineligible because they did not meet the inclusion criteria. A total of $456(84.1 \%)$ patients were finally enrolled and subsequently analyzed. Twenty-eight patients were lost to follow-up and five were hospitalized at the time of the follow-up visit. Finally, 422 patients attended a follow-up visit $10 \pm 3$ days after the screening visit. The average incidence rate of CAP calculated in four of the participating centers varied from 1.2 to 3.5 cases per 1000 persons per year (Table 1). Registered cases of CAP were more frequent in the winter months, especially in January and February.

Table 1. Estimated incidence rates of community-acquired pneumonia (CAP) in four of the participating primary care centers.

\begin{tabular}{ccccc}
\hline $\begin{array}{c}\text { Primary Health Care Center } \\
\text { (Spanish Region) }\end{array}$ & Cases & Population & $\begin{array}{c}\text { Overall Incidence Rate Per } \\
\mathbf{1 0 0 0} \text { Persons (95\% CI) }\end{array}$ & $\begin{array}{c}\text { Average Incidence Rate }{ }^{\mathbf{1}} \text { Per } \\
\mathbf{1 0 0 0} \text { Persons Per Year }\end{array}$ \\
\hline $\begin{array}{c}\text { Ciudad Jardín } \\
\text { (Andalusia) }\end{array}$ & 216 & 29,144 & $7.41(6.51-8.53)$ & 2.47 \\
\hline $\begin{array}{c}\text { Urban } \\
\text { (Basque country) }\end{array}$ & 58 & 8767 & $6.62(5.12-8.54)$ & 2.21 \\
\hline $\begin{array}{c}\text { Buenos aires } \\
\text { (Community of Madrid) }\end{array}$ & 76 & 20,874 & $3.64(2.91-4.55)$ & 3.21 \\
\hline $\begin{array}{c}\text { Burriana II } \\
\text { (Valencian Community) }\end{array}$ & 88 & 8369 & $10.51(8.54-12.94)$ & 2.18 \\
\hline
\end{tabular}

${ }^{1}$ Incidence rate calculated in all patients $\geq 18$ years with CAP confirmed by chest X-ray during the study recruitment period from the four participating centers where a population denominator was established.

Eighteen (3.9\%) of the cases were classified as pneumococcal CAP and the rest (438) as non-pneumococcal CAP according to the results of the Binax Now ${ }^{\circledR}$ test. The mean age of the participants was 56.6 years $( \pm 17.5)$, and $53.5 \%$ were female. Patients from 17 different nationalities participated in the study, most of them (93.93\%) Spanish.

\subsection{Clinical Signs and Symptoms}

Cough, fever and expectoration were the most common symptoms of pneumonia detected at recruitment in $88.16 \%, 70.83 \%$ and $53.73 \%$ of the patients, respectively (Table 2). Expectoration was significantly more present in patients with pneumococcal CAP than in patients with non-pneumococcal CAP $(77.78 \%$ vs. $52.74 \%, p=0.038)$. The frequency of patients with fever and cough was also significantly higher in the sub-population of patients with no underlying conditions than in those with one or more underlying conditions $(79.05 \%$ vs. $63.82 \%$ for fever, $p=0.0004 ; 91.43 \%$ vs. $85.37 \%$ for cough, $p=0.046)$. Conversely, dyspnea was more common in patients with $\geq 1$ underlying condition (38.21\%) than in patients with no underlying conditions $(24.76 \%)$. 
Table 2. Clinical presentation of study population in the whole cohort.

\begin{tabular}{|c|c|c|}
\hline & & $\begin{array}{l}\text { Total Cohort } \\
\quad(n=456)\end{array}$ \\
\hline \multirow{6}{*}{$\begin{array}{l}\text { Signs and symptoms * } \\
\text { n (\%) }\end{array}$} & Fever & $323(70.83 \%)$ \\
\hline & Chills & $187(41.01 \%)$ \\
\hline & Cough & $402(88.16 \%)$ \\
\hline & Expectoration & $245(53.73 \%)$ \\
\hline & Pleuritic chest pain & $166(36.40 \%)$ \\
\hline & Dyspnea & $146(32.02 \%)$ \\
\hline \multirow{7}{*}{$\begin{array}{c}\text { Radiographic features } \# \\
\text { n (\%) }\end{array}$} & Pleural effusion & $18(3.95 \%)$ \\
\hline & Increased lung density due to the infection & $372(81.58 \%)$ \\
\hline & Alveolar infiltrates with air bronchogram & $141(30.92 \%)$ \\
\hline & Multilobar & $9(1.97 \%)$ \\
\hline & Lobar & $89(19.52 \%)$ \\
\hline & Segmental & $43(9.43 \%)$ \\
\hline & Other radiographic findings & $15(3.29 \%)$ \\
\hline
\end{tabular}

${ }^{*}$ All patients presented at least two of the signs and symptoms listed. Fever was defined as temperature higher than $38^{\circ} \mathrm{C}$ in the 24 hours prior to recruitment. ${ }^{\#}$ Radiographic findings were not exclusive.

Regarding radiographical findings consistent with CAP, we found that 372 patients $(81.58 \%)$ had increased lung density due to infection and 141 patients $(30.92 \%)$ had alveolar infiltrates with air bronchogram.

\subsection{Underlying Conditions}

The clinical history of the study population is summarized in Table 3. Just over half of the patients $(53.95 \%)$ presented one or more underlying conditions. The most frequent underlying conditions were diabetes, asthma and chronic obstructive pulmonary disease (COPD), reported in $11.84 \%, 8.55 \%$ and $7.46 \%$ of affected patients, respectively. Nearly $15 \%$ of cases among CAP patients were active smokers or ex-smokers for less than 6 months. We found no significant differences between patients with confirmed pneumococcal CAP and non-pneumococcal CAP. Previous pneumococcal vaccination was reported in 83 patients $(18.20 \%)$; of these $67(80.72 \%)$ had received the polysaccharide vaccine and $27(32.53 \%)$ the PCV13 vaccine. One hundred and sixty-nine CAP patients $(37.6 \%)$ had received the influenza vaccine. Previous history of pneumonia and influenza vaccination was significantly lower in patients with no underlying conditions ( $6.19 \mathrm{vs.} 28.46 \%$ for pneumococcal vaccine and $20.95 \%$ vs. $50.81 \%$ for influenza vaccine, $p<0.0001)$. 
Table 3. Underlying conditions in the study population.

\begin{tabular}{|c|c|c|}
\hline & & $\begin{array}{c}\text { Total Cohort } \\
\quad(n=456)\end{array}$ \\
\hline \multirow{12}{*}{$\begin{array}{l}\text { Underlying conditions } \\
\text { n ( } \%)\end{array}$} & No & $210(46.05 \%)$ \\
\hline & Yes & $246(53.95 \%)$ \\
\hline & COPD & $34(13.82 \%)$ \\
\hline & Asthma & $39(15.85 \%)$ \\
\hline & Congestive heart failure & $15(3.29 \%)$ \\
\hline & Coronary disease & $24(9.76 \%)$ \\
\hline & Chronic kidney disease & $15(3.29 \%)$ \\
\hline & Cerebrovascular disease & $10(4.07 \%)$ \\
\hline & Diabetes & $54(21.95 \%)$ \\
\hline & Previous pneumonia $\S$ & $13(2.85 \%)$ \\
\hline & Smoker* & $66(14.47 \%)$ \\
\hline & Alcoholism \# & $3(0.66 \%)$ \\
\hline \multirow{4}{*}{$\begin{array}{c}\text { Vaccination history } \\
\mathrm{n}(\%)\end{array}$} & Previous pneumococcal vaccine & $83(18.20 \%)$ \\
\hline & PPSV23 & $67(80.72 \%)$ \\
\hline & PCV13 & $27(32.53 \%)$ \\
\hline & Influenza & $169(37.06 \%)$ \\
\hline
\end{tabular}

Percentages calculated over the sample with 1 or more underlying conditions. ${ }^{\S}$ Previous pneumonia within the last 6 months. * More than 10 cigarettes/day ( 0.5 pack-years) in the last year or ex-smoker $<6$ months. " Alcohol intake $\geq 80 \mathrm{~g} /$ day for at least the previous year.

\subsection{Antibiotic Treatments}

Almost all the patients studied $(n=455)$ received antibiotic treatment with an average treatment duration of $9.9 \pm 2.7$ days $(95 \% \mathrm{CI}=9.72-10.22)$. Quinolones and $\beta$-lactams were the most common antibiotics prescribed, used in $58.77 \%(n=268)$ and $31.14 \%(n=142)$ of patients, respectively (Table 4).

Table 4. Antibiotic treatments used in CAP managed in primary care.

\begin{tabular}{|c|c|c|}
\hline & & Total Cohort $(n=456)$ \\
\hline \multicolumn{2}{|c|}{$\beta$-lactam } & $142(31.14 \%)$ \\
\hline \multicolumn{2}{|c|}{ Cephalosporins } & $21(4.79 \%)$ \\
\hline \multicolumn{2}{|c|}{ Macrolides } & $19(4.17 \%)$ \\
\hline \multicolumn{2}{|c|}{ Quinolones } & $268(58.77 \%)$ \\
\hline \multicolumn{2}{|c|}{ Others } & $6(1.32 \%)$ \\
\hline \multirow{4}{*}{ Antibiotic combinations } & Total & $23(5.04 \%)$ \\
\hline & Macrolide $+\beta$-lactam & $9(39.13 \%)$ \\
\hline & Quinolone $+\beta$-lactam & $5(21.74 \%)$ \\
\hline & Other antibiotics combination & $9(39.13 \%)$ \\
\hline
\end{tabular}

\subsection{Outcome}

A total of 422 patients attended their follow-up visit at $10 \pm 3$ days after the screening visit. The percentage of clinical recovery was $65.40 \%$ and mean time to recovery was $14.64 \pm 6.04$ days $(95 \% \mathrm{CI}=13.93-15.36)$. Eight patients were hospitalized within the follow-up period. Mean length of hospital stay was 5.63 days (95\% CI 3.79-7.46). Globally, 
the hospitalization rate after inclusion in the study was $2.8 \%(n=13)$, and no deaths were reported.

\section{Discussion}

Our data provide an updated overview of the characteristics of radiologically confirmed CAP in adults managed in primary care in Spain. We were also able to obtain a current picture of ambulatory CAP patients by describing their clinical and demographic characteristics in addition to the treatments they received, showing that one in three patients does not recover within 7-10 days after starting antibiotic therapy.

Previous studies have examined the significance of ambulatory CAP in the Spanish adult population. A prospective epidemiological study that analyzed the incidence of both hospitalized and ambulatory CAP in adults in the north-east region of Spain during 20022005 reported an annual incidence of 2.6 cases per 1000 elderly persons [13], while a study by Aramburu et al. found an incidence rate of 8.3 cases per 1000 inhabitants and year in the population > 14 years in the north of Spain (Gipuzkoa) [11]. Our results are based on the incidence data of four of the participating primary care centers with average rates ranging from 1.2 to 3.5 cases per 1000 persons per year, with a mean of 2.1 cases per 1000 persons per year. The variability in our data might be explained by differences in the procedure for recording CAP cases in each of the primary care centers included. Thus, our mean incidence could be an underestimation of the real burden of CAP managed on an outpatient basis in Spain. In fact, a slightly higher incidence was reported in another nationwide study performed between 2009 and 2013 in adults with CAP from primary care, with an incidence of 4.63 per 1000 persons/year [14]. In contrast, the discrepancies observed between previous studies and ours could be attributed to differences in the population studied. While some of the studies focused on CAP in patients older than 65 years or included the population between 14 and 18 years, our data were based on adults aged 18 years and older. The region included also differs between these three studies.

S. pneumoniae is globally the leading etiological cause of low-respiratory infections causing more than five times more years lived with disability than the second leading cause (influenza) [15]. In fact, it is also the most frequently identified CAP causative pathogen in ambulatory care, with an estimated prevalence of around 35\% [16]. However, among the 456 patients analyzed in our study, only $18(3.9 \%)$ were positive for S. pneumoniae antigens. One possible explanation for the under detection of pneumococcal CAP in our sample is the low sensitivity of the urine detection test in ambulatory patients. In fact, previous studies have already reported modest sensitivity of the Binax Now ${ }^{\circledR}$ test in adult patients with moderate pneumonia with respect to those classified as severe pneumonia [17]. Interestingly, a Spanish prospective, laboratory-based study also found that the sensitivity of the pneumococcal urinary antigen tests fell from $77.9 \%$, in the period from 2006 to 2010, to $60.5 \%$ between 2011 and 2015 [18]. These variations were associated with changes in C-polysaccharide composition depending on the serotype, producing variations in the sensitivity of urine antigen tests that ranged from $33.3 \%$ to $100 \%$ depending on the serotype [18]. Moreover, we found that $30.9 \%$ of patients presented alveolar condensation with air bronchogram, a radiographic finding frequently associated with pneumococcal pneumonia, reinforcing the hypothesis of underestimation of CAP cases by the Binax Now ${ }^{\circledR}$ test in our sample.

About half of our study population presented one or more comorbidities, being diabetes, asthma and COPD the most commonly reported. Chronic respiratory diseases, including asthma and COPD, were the third leading cause of death in 2017, with an important impact in the quality of life of the patients $[19,20]$. Intriguingly, substantially increased rates of pneumococcal disease have been observed among persons with underlaying risk conditions, such as diabetes or asthma [21]. On the other hand, it is important to consider the negative impact of CAP and pneumococcal disease in the evolution, quality of life and survival of patients with chronic diseases [22]. Therefore, it is crucial to take into consideration the presence of underlying conditions in order to understand the real burden 
of the disease and, consequently, appropriately target the interventions to reduce the risk of infection.

In our cohort, $46.0 \%$ of patients with clinically confirmed CAP did not present any underlying condition. It is interesting that almost half of the radiographically confirmed CAP patients did not have any underlying factors related with CAP, such as COPD or smoking history. Indeed, the study performed by Rivero-Calle et al. in Spanish adults with CAP in primary care between 2009-2013 showed that the incidence of CAP was strongly associated with a high prevalence of multiple lifestyle risk factors and comorbidities [4]. Specifically, less than $30 \%$ of the adult CAP patients included in the study showed no risk factors, while patients $>55$ years had an identified risk factor in $85.7 \%$ of cases [4]. Nevertheless, our study did not specifically analyze the association between risk factors and presence of CAP, as in the aforementioned study. Furthermore, the fact that $65.4 \%$ of our patients recovered from CAP in around 10 days suggests that a significant percentage of the population included in the study presented a mild form of CAP, more likely not associated with an underlying condition.

We found that dyspnea was significantly more common among patients with one or more underlying conditions, than in patients with no clinical history of interest. Since increased perception of dyspnea has been observed in patients with respiratory diseases and in persons with high anxiety/depression levels [23], one could argue that the higher number of patients with dyspnea in our study could, in fact, be associated with the presence of other comorbidities. Previous vaccination with both influenza and pneumonia vaccines was also significantly more frequent in the sub-population of patients with underlying conditions, suggesting that, as recommended by the national health authorities [24,25], people with comorbidities are receiving vaccines against flu and pneumonia, albeit with a low uptake, especially for the pneumococcal vaccine.

Multidisciplinary guidelines for the management of CAP (GNAC) together with the guidelines of the Spanish Society of Pulmonology and Thoracic Surgery (SEPAR) are used by the majority of healthcare professionals in Spain who participate in the care of CAP patients $[16,26,27]$. In terms of the treatment of ambulatory CAP, they recommend a 5-7 day course of quinolones (levofloxacin and moxifloxacin) or dual antibiotic therapy of amoxicillin and a macrolide [16]. This is consistent with the results found in our cohort, with quinolones and $\beta$-lactams being the most common antibiotics prescribed (58.77\% and $31.14 \%$ of patients, respectively), demonstrating that primary care physicians in Spain are correctly following national guidelines. However, we found that the mean duration of treatment was almost 10 days, suggesting that even for moderate CAP cases that do not require hospitalization, professionals are prescribing antibiotic cycles that exceed the necessary duration, even when it has been demonstrated that shorter cycles are more effective in the treatment of CAP [28,29].

This study has some limitations. First, the incidence rate for ambulatory CAP was only calculated in four of the participating centers, and it provides therefore an estimation of the real incidence of non-hospitalized CAP in Spain. Second, the number of confirmed cases of pneumococcal CAP was too low, preventing us from making predictions and association analysis. We may also have missed some CAP cases that were not diagnosed initially in primary care. Nevertheless, our study also has some important strengths. It is a prospective study that includes 24 primary care centers throughout Spain, thus providing a global image of what is happening nationwide. Furthermore, it is important to highlight its population-based design, and that all cases of CAP were radiologically confirmed.

In summary, this multicenter prospective study offers insights into the current situation of non-hospitalized CAP patients aged $\geq 18$ years in Spain, and provides an updated picture of their clinical characteristics, management and evolution, thus increasing awareness of the current burden of the disease treated at primary care level. 
Author Contributions: J.M., F.M.-T., I.C., and C.M. contributed to the conception and design of the work; J.M., A.G.-G., L.G., M.E.P., J.L.J., A.A., G.A., E.Q., J.J.C., A.G., M.L., M.T.M., P.Y.S., L.N., J.G., E.M., J.L., A.C., J.H., M.C.S., E.C., M.P., J.V.A. and D.O. contributed to the acquisition of the data; J.M., F.M.-T. and I.C. contributed to the interpretation of data for the work and drafted the manuscript; all authors reviewed the manuscript critically for important intellectual content and provided final approval of the version to be published. All authors have read and agreed to the published version of the manuscript.

Funding: This study was sponsored by Pfizer. The sponsor participated in the analysis of the data. Study coordinators (J.M. and F.M.-T.) participated with the sponsor in the interpretation of the data. Medical writing support was provided by Medical Statistics Consulting (MSC, Valencia) and funded by Pfizer.

Institutional Review Board Statement: The study was conducted according to the guidelines of the Declaration of Helsinki, and approved by the Institutional Regional Ethics Committee of Madrid (CEIC-R) with the reference PFI-PRE-2015-01 on 12 January 2016.

Informed Consent Statement: Informed consent was obtained from all subjects included in the study.

Data Availability Statement: No new data were created or analyzed in this study. Data sharing is not applicable to this article.

Acknowledgments: The authors sincerely thank the following doctors and nurses, members of the CAPPRIC study group, for their contribution to the recruitment of the study participants and their dedication and support to the CAPPRIC study: Elvira Rubio, Ernesto Cerrada, Jesús Méndez-Cabeza, Gloria Viñas, Hanz Carlos Alache, Katherine Parra, Teresa Ceballos, Lucía Sánchez, Anés Gil, M ${ }^{a}$ Luisa Valés, $\mathrm{M}^{a}$ Ángeles Asensio (Primary Health Care Center Francia. Fuenlabrada, Madrid, Spain); M $^{a}$ Carmen González, M ${ }^{a}$ Lucía Fernández, Pilar Miñano, Paloma Cano, Mª Begoña López, Blanca Fernandez Cuartero Jose $\mathrm{M}^{\mathrm{a}}$ Moral, Ana Contreras, Rosa Pastor, Manuel Campo, Francisco Romero, Antonio Jesús Salvador, Ángel González, Ignacio Morón, Esperanza Gálvez, Carmen Martín, Milagros Montalvo, Elena Mendoza, $\mathrm{M}^{\mathrm{a}}$ Concepción Álvarez, $\mathrm{M}^{\mathrm{a}}$ Antonia Rojo, Fátima López, Rosa Asencio, Marta Guzón, Begoña Vicuña, Ana Carvajal, Juan Carlos Campos, Ma Carmen Sáez, Alejandra Valadez, Elena Merino (Primary Health Care Center Goya. Madrid, Spain); M Carmen González, M ${ }^{\mathrm{a}}$ Lucía Fernández, Pilar Miñano, Paloma Cano, $M^{a}$ Begoña López, Blanca Fernández Cuartero, Jose $M^{a}$ Moral, Ana Contreras, Rosa Pastor, Manuel Campo, Francisco Romero, Antonio Jesús Salvador, Ángel González, Ignacio Morón, Esperanza Gálvez, Carmen Martín, Milagros Montalvo, Elena Mendoza, M $^{a}$ Concepción Álvarez, M ${ }^{a}$ Antonia Rojo, Fátima López, Rosa Asencio, Marta Guzón, Begoña Vicuña, Ana Carvajal, Juan Carlos Campos, $\mathrm{M}^{\mathrm{a}}$ Carmen Sáez, Alejandra Valadez, Elena Merino (Primary Health Care Center Goya. Madrid, Spain); Antonio Baca, Juan Retamero, María Khun, Devorah Gil, Luz Pilar Mota, Ma Rosa Sánchez, Jose Mancera, Jose Luis Cabrera, Jaime Sasporte, $\mathrm{M}^{\mathrm{a}}$ Carmen Mateos, Manuel Izquierdo, Álvaro Milán, Francisca Paniagua, Silvia Mesa, Fernando Frapolli, M ${ }^{a}$ de la Paz Fernández, Miguel Gutiérrez, Salomé Abad, Ana $\mathrm{M}^{\mathrm{a}}$ Cáliz, $\mathrm{M}^{\mathrm{a}}$ Teresa Moreno, Rafael Poyato (Primary Health Care Center Ciudad Jardín. Málaga, Spain); Antonio Hormigo, Aiana Ruiz, Inmaculada Corrales, Ángel Gutierrez, Rafael Jiménez, Jose Manuel Cañizares (Primary Health Care Center Puerta Blanca. Málaga, Spain); Isolina Castellanos, Begoña Guergué, Fernando Uribe, Juan Ignacio Urresti, Amalur Imaz (Primary Health Care Center Urban. Barakaldo, Vizcaya, Spain); Irina Janota, Nuria Relaño, M ${ }^{a}$ Gimena Agostino, Blanca Rosa Hernández, Ma Jesús Guiu, María Vila (Primary Health Care Center Nova Lloreda. Badalona, Barcelona, Spain); Rosa-Ana Castillo, Jose Vicente Crespo, Juan Luis Llosa, Eva Isabel Navio, Ma Dolores Segura (Primary Health Care Center de Burriana II. Burriana, Castellón, Valencia, Spain); Diego Vargas, Francisco José de la Casa, Pablo Berenguel, Antonio Manuel Cordovilla, Cecilia Pérez Díaz (Hospital de Alta Resolución “El Toyo". Almería, Spain); Jesús Vizcaíno, Juan Luís Frigola, Coral Chancho, $\mathrm{M}^{\mathrm{a}}$ José Forcadell, Joaquín $\mathrm{M}^{\mathrm{a}}$ García, Ramón Sagarra (Primary Health Care Center Sant Pere. Reus, Tarragona, Spain); M $^{a}$ Mar Fraj, Gemma Ara, Ma Puy Gorgojo, Ma Pilar Nogué, Marta Rodríguez, Antonia Ferré, Ma José Roy, Damián Valgañón, Ana Isabel Sánchez, Claudia Gaudo (Primary Health Care Center Fernando el Católico. Zaragoza, Spain); Paloma González, Rocío Susana Ruiz, Renata Muñoz, Laura Santos, Alberto Manzanares, Raquel Baños, Ana Ma Ibarra, Javier Muñoz, Elena Barahona, Ana Oresanz, Jorge Casas, Cármen Abascal (Primary Health Care Center Buenos Aires. Madrid, Spain); Ma José San Telesforo, Marta Bosom, $\mathrm{M}^{\mathrm{a}}$ Luisa Riestra, Pilar Chaves (Primary Health Care Center General Ricardos. Madrid, Spain); Jose Javier Valdeperez, José Luis Antonio, Carlos Arruga, Carmen Sisamón, Pilar Suñen, Rogelio Antisent, Adoración Codina, Úrsula Alvira, $\mathrm{M}^{\mathrm{a}}$ Elena Marque, Matilde Cavero, 
Sonia Sanz Sebastian, Daniel Ferrer, Daniel Juncosa, Diego Pueyo, Sara Causape, Ma Asunción Robles, José Luis Matías (Primary Health Care Center Actur Sur. Zaragoza, Spain); Ma Berta Anta, Catalina del Río Navarro (Primary Health Care Center Barrio de la Salud. Santa Cruz de Tenerife, Spain); M $^{a}$ Jesús Cobas, Leopoldo García, Rosa $\mathrm{M}^{\mathrm{a}}$ Rodríguez, Lourdes Verez (Primary Health Care Center de Matamá. Vigo, Pontevedra, Spain); Ana Casorrán, Jazmín Ripoll, Pilar Ayuso, Alejandro Salanova, Ana José Ortuño, Amparo Fransi, Ángel Collado, José Ignacio Sánchez, Luis Ibañez (Primary Health Care Center Fuente San Luis. Valencia, Spain); Roberto Moreno, Laura Cuevas, José Antonio Álvaro, Sandra González, Sergio Rivero, Sara Carrillo, Joaquín Díaz, Enrique Cazalla, Encarnación Montes, $\mathrm{M}^{\mathrm{a}}$ Dolores Rodríguez, Ana Candau, Juan Manuel Sánchez, Juan Fernández, Ángel José Aumesquet, Antonia Rico, Carmen Aguayo, Pilar Vaquero (Primary Health Care Center Utrera Norte Príncipe de Asturias. Utrera, Sevilla, Spain); Silvia Medrano, Rosario Ruiz, Julio J. Turrientes, $\mathrm{M}^{\mathrm{a}}$ Cristina Santos, Pilar Pérez, Alberto Serrano, Esmeralda Alonso, Almudena Uranga, $M^{\text {a }}$ Eugenia Calonge, Adelaida Iglesias, Teresa Galan, Fernando Barcala (Primary Health Care Center García Noblejas. Madrid, Spain); Teresa Antón, Carmen Mugarza, Ana Isabel Izaguirre (Primary Health Care Center Los Comuneros. Burgos, Spain); Concepción Estelles, América Pujades (Primary Health Care Center Just Ramírez. Valencia, Spain); Marisol Guerra, Moisés Robledo, Paloma Vírgula (Primary Health Care Center Contrueces. Gijón, Asturias, Spain); Pilar Rosales (CAP Sant Llàtzer. Terrasa, Barcelona, Spain); Luis García-Giralda, Isabel Casas (Centro Salud Murcia Centro - San Juan. Murcia, Spain); M $^{\mathrm{a}}$ Carmen Molina, Antonio José Manzano, Sebastián Gonzalez, Patricia Clavero, Inmaculada Marfil, Miriam Contreras (Primary Health Care Center Algeciras-Norte. Algeciras, Cádiz, Spain). In addition, the authors would also like to thank the dedication and support provided by the following CRAs and CTAs, César Balseiro, Arancha García, Juan Sáez, Aránzazu Perianes, Antonio Díaz, Carolina Carcel, Eduardo Fernández, Ernesto Garijo, Juan Martínez (TFS at Pfizer); the collaboration and support of $\mathrm{M}^{\mathrm{a}}$ Luz Samaniego for the statistical analysis (TFS at Pfizer); and the medical writing support provided by Vanessa Marfil Vives (Medical Statistics Consulting S.L. Valencia, Spain).

Conflicts of Interest: J.M., A.G.-G., L.G., M.E.P., J.L.J., A.A., G.A., E.Q., J.J.C., A.G., M.L., M.T.M., P.Y.S., L.N., J.G., E.M., J.L., A.C., J.H., M.C.S., E.C., M.P., J.V.A., F.M.-T. and D.O. reports grants to their institutions from Pfizer S.L.U., Madrid, Spain for this study; J.M. has received personal fees from AstraZeneca, GSK, Chiesi and Novartis, during the conduct of the study; F.M.-T. has received honoraria from GSK, Pfizer S.L.U., Sanofi Pasteur, MSD, Seqirus, and Janssen for taking part in advisory boards and expert meetings, and for acting as speaker in congresses outside the scope of the submitted work. FM-T has also acted as principal investigator in RCTs of the above-mentioned companies, and Ablynx, Regeneron, Roche, Abbott, Novavax, and MedImmune, with honoraria paid to his institution; D.O. reports personal fees from Pfizer S.L.U., during the conduct of the study; personal fees from Sanofi Pasteur and Seqirus and non-financial support from Sanofi Pasteur and from MSD, outside the submitted work; I.C. and C.M. are employees of Pfizer S.L.U., Madrid, Spain.

\section{References}

1. Murdoch, D.R.; Howie, S.R.C. The global burden of lower respiratory infections: Making progress, but we need to do better. Lancet Infect. Dis. 2018, 18, 1162-1163. [CrossRef]

2. Jain, S.; Self, W.H.; Wunderink, R.G.; Fakhran, S.; Balk, R.; Bramley, A.M.; Reed, C.; Grijalva, C.G.; Anderson, E.J.; Courtney, D.M.; et al. Community-Acquired Pneumonia Requiring Hospitalization among U.S. Adults. N. Engl. J. Med. 2015, 373, 415-427. [CrossRef] [PubMed]

3. Cillóniz, C.; Rodríguez-Hurtado, D.; Torres, A. Characteristics and Management of Community-Acquired Pneumonia in the Era of Global Aging. Med. Sci. 2018, 6, 35. [CrossRef]

4. Rivero-Calle, I.; Pardo-Seco, J.; Pardo-Seco, J.; Aldaz, P.; Vargas, D.A.; Mascarós, E.; Redondo, E.; Díaz-Maroto, J.L.; Linares-Rufo, M.; Fierro-Alacio, M.J.; et al. Incidence and risk factor prevalence of community-acquired pneumonia in adults in primary care in Spain (NEUMO-ES-RISK project). BMC Infect. Dis. 2016, 16, 1-8. [CrossRef]

5. Sicras-Mainar, A.; Ibáñez-Nolla, J.; Cifuentes, I.; Guijarro, P.; Navarro-Artieda, R.; Aguilar, L. Retrospective epidemiological study for the characterization of community-acquired pneumonia and pneumococcal pneumonia in adults in a well-defined area of Badalona (Barcelona, Spain). BMC Infect. Dis. 2012, 12, 283. [CrossRef]

6. Cilloniz, C.; Ewig, S.; Polverino, E.; Marcos, M.A.; Prina, E.; Sellares, J.; Ferrer, M.; Ortega, M.; Gabarrus, A.; Mensa, J.; et al. Community-acquired pneumonia in outpatients: Aetiology and outcomes. Eur. Respir. J. 2012, 40, 931-938. [CrossRef] [PubMed]

7. Cillóniz, C.; Ewig, S.; Polverino, E.; Marcos, M.A.; Esquinas, C.; Gabarrús, A.; Mensa, J.; Torres, A. Microbial aetiology of community-acquired pneumonia and its relation to severity. Thorax 2011, 66, 340-346. [CrossRef] [PubMed]

8. Troeger, C.; Blacker, B.; A Khalil, I.; Rao, P.C.; Cao, J.; Zimsen, S.R.M.; Albertson, S.B.; Deshpande, A.; Farag, T.; Abebe, Z.; et al. Estimates of the global, regional, and national morbidity, mortality, and aetiologies of lower respiratory infections in 195 countries, 1990-2016: A systematic analysis for the Global Burden of Disease Study 2016. Lancet Infect. Dis. 2018, 18, 1191-1210. [CrossRef] 
9. Reller, L.B.; Weinstein, M.P.; Werno, A.M.; Murdoch, D.R. Laboratory Diagnosis of Invasive Pneumococcal Disease. Clin. Infect. Dis. 2008, 46, 926-932. [CrossRef] [PubMed]

10. Said, M.A.; Johnson, H.L.; Nonyane, B.A.S.; Deloria-Knoll, M.; O'brien, K.L. For the AGEDD Adult Pneumococcal Burden Study Team Estimating the Burden of Pneumococcal Pneumonia among Adults: A Systematic Review and Meta-Analysis of Diagnostic Techniques. PLoS ONE 2013, 8, e60273. [CrossRef] [PubMed]

11. Aramburu, M.I.I.; Beguiristain, M.A.A.; Carretero, M.J.I.; Campos, J.M.; Perez, P.E.; Gorosabel, R.G. Epidemiología de la neumonía adquirida en la comunidad. Prim. Care 2013, 45, 503-513. [CrossRef]

12. Alere BinaxNOW ${ }^{\mathrm{TM}}$ Streptococcus Pneumoniae Antigen Card. Available online: www.alere.com/en/home/product-details/ binaxnow-streptococcus-pneumoniae.html (accessed on 2 December 2020).

13. Córcoles, Á.V.; Blanco, T.R.; Gondar, O.O.; Serrano, E.S.; Cabanes, C.D.D.; López, A.V. Incidencia y características clínicas de las neumonías tratadas ambulatoriamente en las personas mayores de 65 años del área de Tarragona-Valls, 2002-2005. Rev. Span. Public Health 2009, 83, 321-329. [CrossRef]

14. Gil-Prieto, R.; García-García, L.; Álvaro-Meca, A.; Méndez, C.; García, A. Gil De Miguel, Ángel the burden of hospitalisations for community-acquired pneumonia (CAP) and pneumococcal pneumonia in adults in Spain (2003-2007). Vaccine 2011, 29, 412-416. [CrossRef]

15. James, S.L.; Abate, D.; Abate, K.H.; Abay, S.M.; Abbafati, C.; Abbasi, N.; Abbastabar, H.; Abd-Allah, F.; Abdela, J.; Abdelalim, A.; et al. Global, regional, and national incidence, prevalence, and years lived with disability for 354 diseases and injuries for 195 countries and territories, 1990-2017: A systematic analysis for the Global Burden of Disease Study 2017. Lancet 2018, 392, 1789-1858. [CrossRef]

16. Torres, A.; Barberán, J.; Falguera, M.; Menendez, R.; Molina, J.; Olaechea, P.; Rodríguez, A. Guía multidisciplinar para la valoración pronóstica, diagnóstico y tratamiento de la neumonía adquirida en la comunidad. Med. Clin. 2013, 140, 223.e1-223.e19. [CrossRef] [PubMed]

17. Zhou, F.; Gu, L.; Qu, J.; Liu, Y.; Cao, B.; Network, F.C.-C. Evaluating the utility of Binax NOW Streptococcus pneumoniae urinary antigen test in adults with community acquired pneumonia in China. Clin. Respir. J. 2016, 12, 425-432. [CrossRef]

18. Shoji, H.; Domenech, A.; Simonetti, A.F.; González, A.; García-Somoza, D.; Cubero, M.; Martí, S.; Maeda, M.; Tubau, F.; Liñares, J.; et al. The Alere BinaxNOW Pneumococcal Urinary Antigen Test: Diagnostic Sensitivity for Adult Pneumococcal Pneumonia and Relationship to Specific Serotypes. J. Clin. Microbiol. 2017, 56, e00787-e00817. [CrossRef]

19. Soriano, J.B.; Abajobir, A.A.; Abate, K.H.; Abera, S.F.; Agrawal, A.; Ahmed, M.B.; Aichour, A.N.; Aichour, I.; Aichour, M.T.E.; Alam, K.; et al. Global, regional, and national deaths, prevalence, disability-adjusted life years, and years lived with disability for chronic obstructive pulmonary disease and asthma, 1990-2015: A systematic analysis for the Global Burden of Disease Study 2015. Lancet Respir. Med. 2017, 5, 691-706. [CrossRef]

20. Soriano, J.B.; Kendrick, P.J.; Paulson, K.R.; Gupta, V.; Abrams, E.M.; Adedoyin, R.A.; Adhikari, T.B.; Advani, S.M.; Agrawal, A.; Ahmadian, E.; et al. Prevalence and attributable health burden of chronic respiratory diseases, 1990-2017: A systematic analysis for the Global Burden of Disease Study 2017. Lancet Respir. Med. 2020, 8, 585-596. [CrossRef]

21. Shea, K.M.; Edelsberg, J.; Weycker, D.; Farkouh, R.A.; Strutton, D.R.; Pelton, S.I. Rates of Pneumococcal Disease in Adults with Chronic Medical Conditions. In Open Forum Infectious Diseases; Oxford University Press: Oxford, UK, 2014; Volume 1. [CrossRef]

22. Torres, A.; E Peetermans, W.; Viegi, G.; Blasi, F. Risk factors for community-acquired pneumonia in adults in Europe: A literature review. Thorax 2013, 68, 1057-1065. [CrossRef] [PubMed]

23. Laviolette, L.; Laveneziana, P. A multidimensional and multidisciplinary approach. Eur. Respir. J. 2014, 43, 1750-1762. [CrossRef]

24. Comisión de Salud Pública. Recomendaciones de Vacunación Frente a la Gripe. 2020. Available online: www.mscbs.gob. es/profesionales/saludPublica/prevPromocion/vacunaciones/docs/Recomendaciones_vacunacion_gripe.pdf (accessed on 2 December 2020).

25. Ministerio de Sanidad. Vacunación en Grupos de Riesgo de Todas las Edades y en Determinadas Situaciones. 2018. Available online: www.mscbs.gob.es/profesionales/saludPublica/prevPromocion/vacunaciones/VacGruposRiesgo/docs/ VacGruposRiesgo_todas_las_edades.pdf (accessed on 2 December 2020).

26. Menéndez, R.; Torres, A.; Aspa, J.; Capelastegui, A.; Prat, C.; De Castro, F.R. Neumonía adquirida en la comunidad. Nueva normativa de la Sociedad Española de Neumología y Cirugía Torácica (SEPAR). Arch. Bronconeumol. 2010, 46, 543-558. [CrossRef] [PubMed]

27. Menéndez, R.; Cilloniz, C.; España, P.P.; Almirall, J.; Uranga, A.; Méndez, R.; Rigau, D.; Torres, A. Neumonía adquirida en la comunidad. Normativa de la Sociedad Española de Neumología y Cirugía Torácica (SEPAR). Actualización 2020. Arch. Bronconeumol. 2020, 56, 1-10. [CrossRef] [PubMed]

28. Spellberg, B.; Rice, L.B. Duration of Antibiotic Therapy: Shorter Is Better. Ann. Intern. Med. 2019, 171, 210-211. [CrossRef] [PubMed]

29. Vaughn, V.M.; Flanders, S.A.; Snyder, A.; Conlon, A.; Rogers, M.A.; Malani, A.N.; McLaughlin, E.; Bloemers, S.; Srinivasan, A.; Nagel, J.; et al. Excess Antibiotic Treatment Duration and Adverse Events in Patients Hospitalized with Pneumonia. Ann. Intern. Med. 2019, 171, 153-163. [CrossRef] 